\title{
Location of a new ice core site at Talos Dome (East Antarctica)
}

\author{
Stefano Urbini ( ${ }^{1}$ ), Lili Cafarella $\left({ }^{1}\right)$, Achille Zirizzotti $\left({ }^{1}\right)$, Cesidio Bianchi $\left({ }^{1}\right)$, \\ Ignazio Tabacco $\left({ }^{2}\right)$ and Massimo Frezzotti $\left({ }^{3}\right)$ \\ (') Istituto Nazionale di Geofisica e Vulcanologia, Roma, Italy

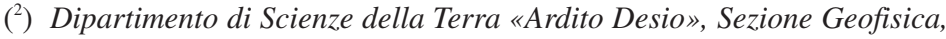 \\ Università degli Studi di Milano, Italy \\ $\left(^{3}\right)$ ENEA - CRE Casaccia, S. Maria di Galeria (RM), Italy
}

\begin{abstract}
In the frame of glaciology and palaeoclimate research, Talos Dome $\left(72^{\circ} 48^{\prime} \mathrm{S} ; 159^{\circ} 06^{\prime} \mathrm{E}\right)$, an ice dome on the East Antarctic plateau, represents the new selected site for a new deep ice core drilling. The increasing interest in this region is due to the fact that the ice accumulation is higher here than in other domes in East Antarctica. A new deep drilling in this site could give important information about the climate changes near the coast. Previous papers showed that the dome summit is situated above a sloped bedrock. A new position on a relatively flat bedrock 5-6 km far from here in the SE direction was defined as a possible new ice core site for an European (Italy, France, Swiss and United Kingdom) drilling project named as TALDICE (TALos Dome Ice Core Project). This point, named as ID1 $\left(159^{\circ} 11^{\prime} 00^{\prime \prime} \mathrm{E} ; 72^{\circ} 49^{\prime} 40^{\prime \prime} \mathrm{S}\right)$, became the centre of the Radio Echo Sounding (RES) flight plan during the 2003 Italian Antarctic expedition, with the aim of confirming the new drilling site choice. In this paper 2001 and 2003 RES data sets have been used to draw a better resolution of ice thickness, bottom morphology and internal layering of a restricted area around the dome. Based on the final results, point ID1 has been confirmed as the new coring site. Finally, the preliminary operations about the installation of the summer ice core camp (TALDICE) at ID1 site carried out during the XX Italian Antarctic expedition (November 2004-December 2005) are briefly described.
\end{abstract}

Key words radio echo sounding - radio glaciology - ice thickness measurements - internal layering

\section{Introduction}

Talos Dome is an ice dome at $72^{\circ} 48^{\prime} \mathrm{S}$; $159^{\circ} 06^{\prime} \mathrm{E}$ on the edge of the East Antarctic plateau adjacent to the Victoria Land mountain about $290 \mathrm{~km}$ from the Southern Ocean and 250 $\mathrm{km}$ from the Ross Sea. This site has a good geochemical and palaeoclimate record preserved in the ice, because the accumulation $\left(80 \mathrm{~kg} \mathrm{~m}^{-2} \mathrm{a}^{-1}\right)$

Mailing address: Dr. Stefano Urbini, Istituto Nazionale di Geofisica e Vulcanologia, Via di Vigna Murata 605, 00143 Roma, Italy; e-mail: urbinis@ingv.it is higher here than at other domes in East Antarctica. Moreover, according to the thickness/snow accumulation ratio, a 120-150 thousand years (BP) palaeoclimatologic history is expected (Deponti and Maggi, 2003). For this reasons Talos Dome, from previous studies (Frezzotti et al., 2003), was selected as new drilling site in order to study the response of near-coastal sites to climate change and Holocene history of accumulation rates in the Ross Sea region. The knowledge of bedrock topography of Talos Dome region and its internal layering are of great importance, not only for the obvious reason of knowing how deep to drill, but also because the lower part of deep ice cores can only be dated by modelling studies (Reeh et al., 1985).

In this paper, a reconstruction of ice thickness, bedrock morphology and some internal layers has been made by Radio Echo Sounding 
data analysis. RES system is an active remotesensing method based on the generation, propagation and reflection of an electromagnetic wave due to one or more discontinuities in the media dielectric properties (Bogorodsky et al., 1985).

This work reports the results obtained by the integration of the last two Antarctic campaigns (2001 and 2003) focused on the selection of the Talos Dome best drilling site position. The 2003 survey was planned to achieve a more detailed information in the area close to the topographic summit of Talos Dome.

\section{Field data acquisition and analysis}

Since 1997 the Istituto Nazionale di Geofisica e Vulcanologia (INGV) and University of Milan have been developing their own airborne radio echo sounding system for remote-sensing studies of the polar ice sheet and glaciers in
Antarctica (for details see Tabacco et al., 1999). This system (named INGV-IT, Tabacco et al., 2002) has been used to map ice thickness and internal layers of glaciers, ice sheets and ice shelves (Tabacco et al., 1998, 2000; Capra et al., 2000; Frezzotti et al., 2000; Remy and Tabacco, 2000; Bianchi et al., 2001; Siegert et al., 2001).

The RES system has been slightly modified during each expedition. Main radar system improvements have been applied between 1996 and 2001 concerning the total range time (which increased from $51.2 \mu \mathrm{m}$ to $64 \mu \mathrm{m}$ ), the number of samples for each radar track (enhanced from 1024 to 1280 samples) and the number of acquired tracks per second (raised from 0.3 track s$^{-1}$ to 10 tracks s$^{-1}$ ).

Figure 1 shows the aircraft legs along which the measurements have been recorded during 2001 and 2003 expeditions (black and red lines respectively) in UTM coordinates WGS84. About $18 \%$ of data could not be used due to the

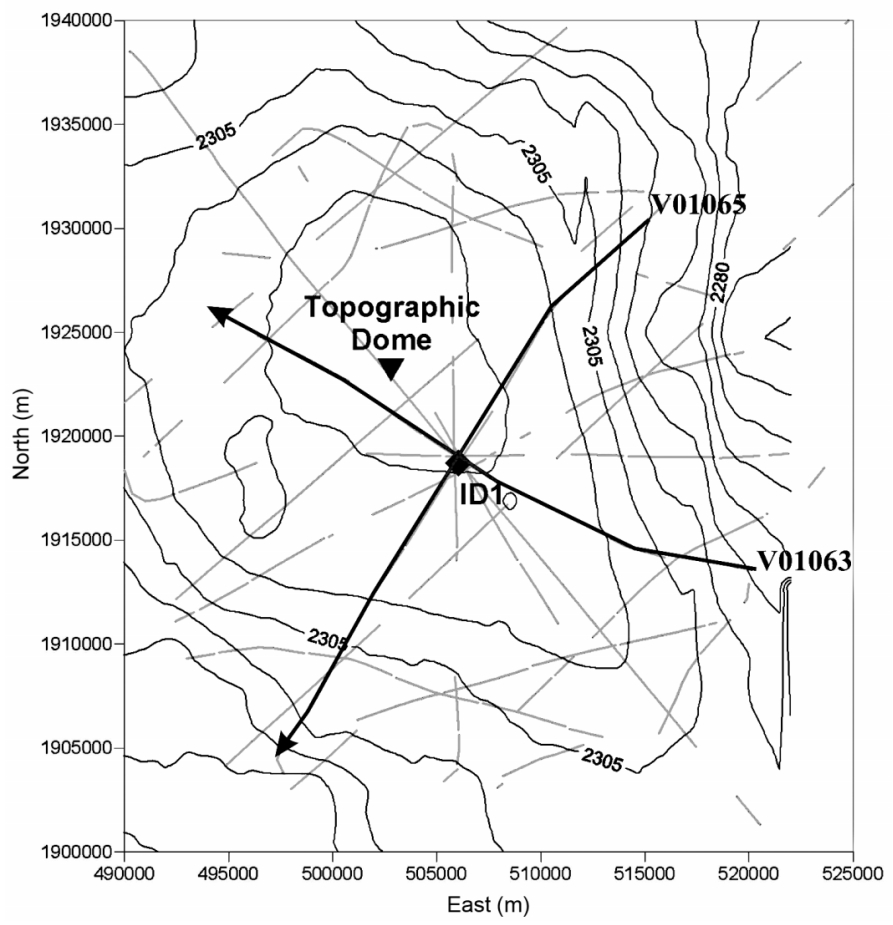

Fig. 1. Aircraft legs covered during 2001 and 2003 Italian Antarctic RES expeditions (black and light grey lines respectively). The position of the selected drilling site is indicated as ID1. 
lack of returned echoes from the bedrock but, on the whole, results can be considered good. In fig. 1 flight lines are interrupted where the bedrock reflection signal has not been received.

The first data set (2001) did not permit the detecting of regular and continuous internal layers especially in the dome area. The technical improvements introduced in the 2003 RES instrumentation allowed to identify three reflecting horizons characterized by good regularity and continuity.

RES raw data post-processing flow consisted basically in deconvolution, gain adjustment, vertical and horizontal filtering, data stacking and, in some cases, migration. All data were processed following the same criteria and finally were cross-checked. Crossover point analysis pointed out that ice thickness values in different RES profiles are in good agreement. Indeed, counted cross points on all legs were 59: $30 \%$ of cross points exceed a distance greater than $200 \mathrm{~m}$ and about $51 \%$ have a difference in ice thickness less than $40 \mathrm{~m}$. Ice thickness was calculated using a

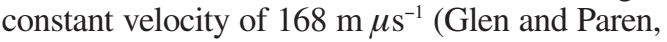
1975; Bogorodsky et al., 1985) while spatial resolution was around $1 \mathrm{scan} / 7 \mathrm{~m}$.

After the described preliminary analysis the same processing parameters (and not the processing flow) have been changed for a better layering resolution.

Whole 2001 and 2003 RES data sets have been used to model the three-dimensional view of the bedrock topography and of the internal layering. The investigated region covers an area of about $1400 \mathrm{~km}^{2}$. All thickness profiles data sets have been gridded by Kriging method with a square grid cell size of about $500 \mathrm{~m}$.

A preliminary RES data analysis pointed out that Talos Dome is a mountainous area with a rough morphology as the neighbouring Frontier Mountains region. Moreover, the RES survey of the investigated area did not show evidences of subglacial lakes or basal melting.

\section{Drilling site characteristics}

It is known that a good drilling site has to be characterized by a relatively flat condition of both the bedrock and the main internal layering.
In fact, an accurate time-depth core correlation is possible only where regular and horizontal snow layering occurs. Moreover, in this area, snow radar and GPS surveys show that the shallow $(100 \mathrm{~m})$ internal layering is continuous and horizontal up to $15 \mathrm{~km}$ from the summit (Frezzotti et al., 2004).

Figure 2 shows the ice surface and sub-glacial topography of the Talos Dome region. A detailed surface elevation map was made using data from many GPS altimeter surveys. The geographic position of Talos Dome, located at Long $159^{\circ} 04^{\prime} \mathrm{E}$ and Lat $72^{\circ} 46^{\prime} \mathrm{S}$ (Frezzotti et al. 1998,2003 ) is indicated in the figure by a triangle symbol. The bedrock depths have been referred to the accurate elevation model obtained using the altimetric measurements for the whole investigated area. As shown, the bedrock topography consists of a deep basin where the ice thickness ranges from 800 to $2900 \mathrm{~m}$. The deep basin is connected to a low bedrock zone. In particular, bedrock of the Talos Dome Summit (TDS) is about $440 \mathrm{~m}$ in elevation (WGS84) and it is covered by about $1900 \mathrm{~m}$ of ice. The dome summit is situated above a sloped bedrock over a kind of isolated ridge and for this reason it is not the ideal drilling site. Following the main ridge structure (elongated to SE direction) 5-6 $\mathrm{km}$ far from this point, bedrock became relatively flat and it is characterized by an elevation of about $750 \mathrm{~m}$ (WGS84) covered by $1550 \mathrm{~m}$ of ice (Frezzotti et al., 2003). This point, named ID1 $\left(159^{\circ} 11^{\prime} 00^{\prime \prime} \mathrm{E} ; 72^{\circ} 49^{\prime} 40^{\prime \prime} \mathrm{S}\right.$ indicated as a black square in the figures 1 and 2) was the centre of the 2003 RES flight plan. Previous campaign data analysis showed also the presence of internal layering below the dome, but reflecting horizons were irregular and discontinuous. By a focused data post processing, 2003 RES dataset allowed to detect three internal layers $(L 1=1850$ $\mathrm{m} ; L 2=1690 \mathrm{~m} ; L 3=1240 \mathrm{~m}$ (WGS84)) characterized by a good continuity along the profiles.

Mountain and valley morphologies orientation follows the ice-divide line (NW-SE) and clearly influence the dome and the internal layers stratigraphy.

The new more detailed 3D maps carried out by 2001-2003 RES datasets integration, also supported by new internal layering analysis (fig. 3), confirm that the position of point ID1 

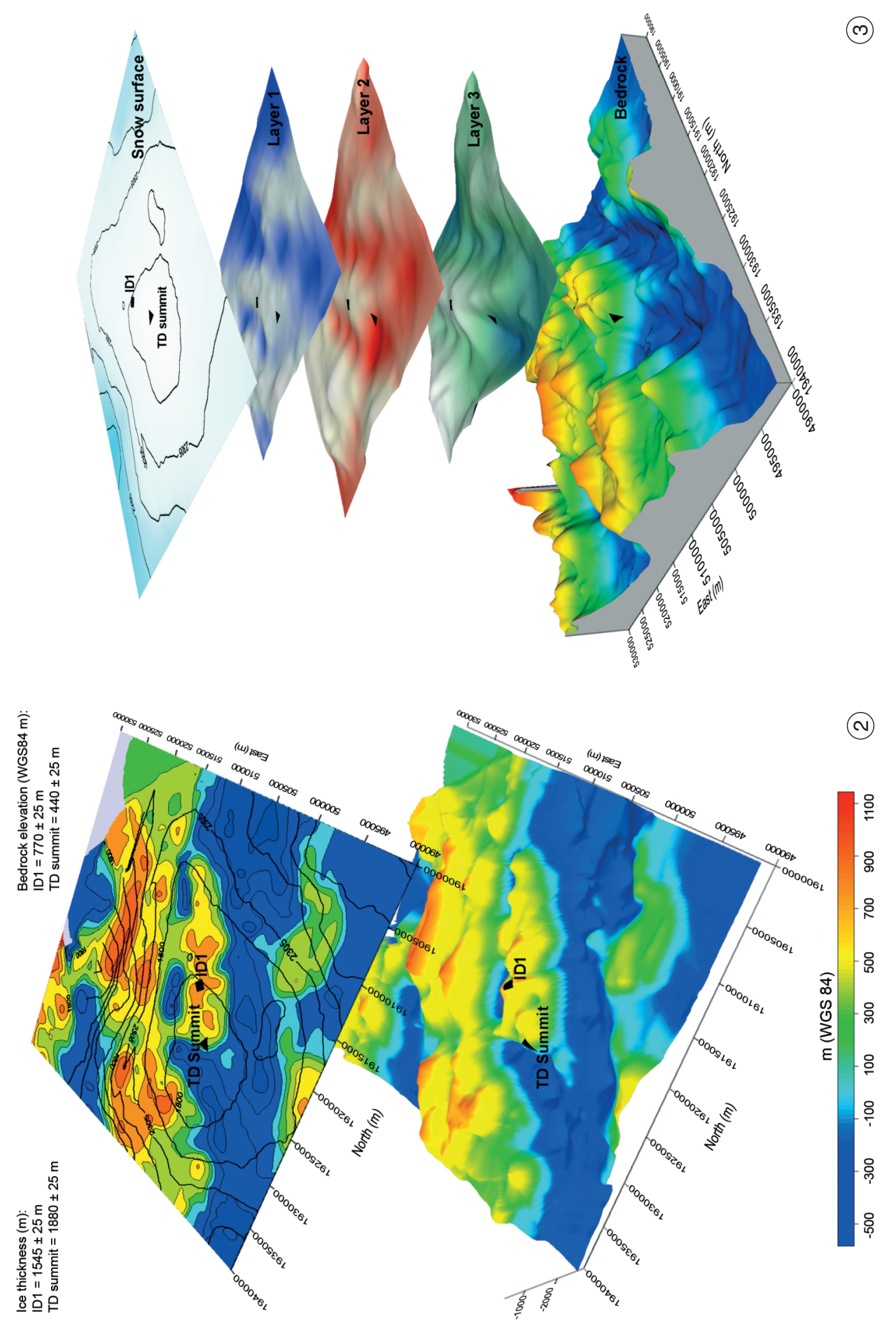

(อ)

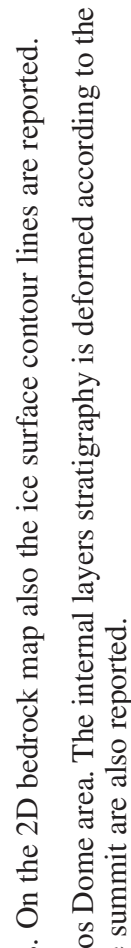
욜 을 范 คे ठे है

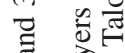
ह ड़े 그름ำ $\Xi$ 즈

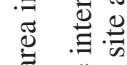
ฮ 芒寻 ค ㅋำ 을 츨: \& I 율 त्ञ̃ 矛 용 월 巳 늄 పे की त 显家 
can be considered a good choice for a new deep ice drilling.

Based on the above considerations, during the XX Italian Antarctic expedition (austral summer 2004-2005), some preliminary works were carried out in order to start the drilling operations. Once localized ID1 point, a wide trench $(50 \times 5.5 \mathrm{~m})$ was excavated by a Pisten Bully in order to contain all drilling instrumentations. Coring operations started, reaching the depth of about $128 \mathrm{~m}$. The coring project plan (TALDICE) foresees the end of the drilling operations in the next two austral summer campaign.

\section{Conclusions}

Talos Dome is an ice dome on the Antarctic plateau $250 \mathrm{~km}$ from the Ross Sea and about $290 \mathrm{~km}$ from the Southern Ocean. It was selected as new drilling site to study the response of near-coastal sites to climate change. Frezzotti et al. (2003) showed that the dome summit was not the ideal drilling site because it is situated above a sloped bedrock and they defined a new point on a relatively flat bedrock, 5-6 km more to the SE. This point, named ID1 was deeply investigated during 2003 Italian Antarctic RES survey.

The integrated 2001 and 2003 RES data sets allowed a better resolution of ice thickness, bottom morphology and some internal layering of a restricted area around the dome, in order to confirm ID1 as the new drilling site. Datasets were collected by airborne INGV-IT radar and cover an area of about $1400 \mathrm{~km}^{2}$ around the dome. This paper shows the bedrock of the investigated region in two and three-dimensional maps. Moreover, ice surface topography defined by GPS altimeter has been reported to have a more complete view of the region. Data analysis confirmed that Talos Dome summit was an inadequate drilling site. On the other hand, ID1 site was localized on the top of a buried mountain ridge where both bedrock and internal layering showed a flat and regular trend. Considering that snow radar and GPS surveys (conducted on the Talos Dome area) showed that the shallow $(100 \mathrm{~m})$ internal layer- ing is continuous and horizontal up to $15 \mathrm{~km}$ from the summit (Frezzotti et al., 2003), the results carried out by the 2001-2003 RES data integration confirmed ID1 position as a potential optimal drilling site.

These results were used during the last XX Italian Antarctic campaign (austral summer 2004-2005), in which some preliminary work was carried out to start the new drilling operations. Coring operations started, reaching the depth of about $128 \mathrm{~m}$. The coring project plan (TALDICE) foresees the end of the drilling operations in the next two austral summer campaigns.

\section{Acknowledgements}

Research was carried out in the framework of the Project on Glaciology and Paleoclimatology of the Italian PNRA National Antarctic Program. Authors wish to thank the anonymous reviewers for their critical and useful observations.

\section{REFERENCES}

Bianchi, C., M. Chiappini, I.E. Tabacco, A. Passerini, A. ZirizZOTTI and E. ZuCCHERETTI (2001): Morphology of bottom surfaces of glacier ice tongues in the East Antartic region, Ann. Geofis., 44 (1), 127-135.

Bogorosky, V.V., C.R. Bentley and P.E. Gudmandsen, (1985): Radioglaciology (D. Reidel Publishing Co. Dordrecht), pp. 272.

Capra, A., R. Cefalo, S. Gandolfi, G. Manzoni, I.E. TaBACCO and L. VitTUARI (2000): Surface topography of Dome Concordia (Antarctica) from kinematic interferential GPS and bedrock topography, Ann. Glaciol., 30 (1), 42-46.

Deponti, A. and V. MaGgi (2003): Age versus depth modelling for Talos Dome, Terra Antarctica Rep., 8, 113-116.

FrezzotTI, M., O. Flora and S. Urbini (1998): The Italian ITASE expedition from Terra Nova station to Talos Dome, Terra Antarctica Rep., 2, 105-108.

Frezzotti, M., I. E. TABACCO and A. ZirizzotTI (2000): Ice discharge of eastern dome $\mathrm{C}$ drainage area, Antarctica, determined from airborne radar survey and satellite image analysis, J. Glaciol., 46 (153), 253-264.

Frezzotti, M., G. Bitelli, S. Gandolfi, P. De Michelis, F. Mancini, S. Urbini, L. Vittuari and A. Zirizzotti (2003): Geophysical survey at Talos Dome (East Antartica), Terra Antartica Rep., 8, 117-120.

Frezzotti, M., M. Pourchet, O. Flora, S. Gandolfi, M. Gay, S. Urbini, C. Vincent, S. Becagli, R. Gragnani, M. Proposito, M. SEVEri, R. Traversi, R. Udisti and M. FILY (2004): New estimations of precipitation and surface 
sublimation in East Antarctica from snow accumulation measurements, Climate Dyn., 23 (7-8), 803-813.

GLEN, J.W. and J.G. PAREN (1975): The electrical properties of snow and ice, J. Glaciol., 15 (73), 15-38.

REEH, N., S.J. JoHNSEN and D. DAHL-JENSEN (1985): Dating Dye 3 deep ice core by flow model calculations, in Greenland Ice core: Geophysics, Geochemistry and the Environment, edited by CC. LANGWAY JR., H. OESCHGER and W. DAnsgaArd, Am. Geophys. Un., Geophys. Monogr. Ser., 33, 57-65.

REMY, F. and I.E. TABACCO (2000): Bedrock features and ice flow near the Epica ice core site (Dome C, Antarctica), Geophys. Res. Lett., 27 (3), 405-408.

SiEgERT, M.J., R.D. Eyers and I.E. TABACCO (2001): Threedimensional ice sheet structure at Dome C, central East Antarctica: implications for the interpretation of the Epica ice core, Antarctic Sci., 13, 182-187.

Tabacco, I.E., A. Passerini, F. Corbelli and M. Gorman (1998): Determination of the surface and bed topography at Dome C, East Antarctica, J. Glaciol., 44, 185-191.

Tabacco, I.E., C. Bianchi, M. Chiappini, A. PAsserini, A. ZirizZotti and E. ZuCCheretTi (1999): La test improvements for the echo sounding system of the Italian radar glaciological group and measurements in Antartica, Ann. Geofis., 42 (2), 271-276.

TABACCO I.E., C. BiANChI, M. ChiapPini, A. ZirizZOTTI and E. ZuCCHERETTI (2000): Analysis of bottom morphology of the David Glacier-Drygalsky Ice Tongue, East Antarctica, Ann. Glaciol., 30, 47-51.

Tabacco, I.E., C. Bianchi, M. Chiappini, A. Zirizzotti, E. Zuccheretti, A. Forieri and A. Della Vedova (2002): Airborne radar survey above Vostok region, east-central Antarctica: ice thickness and Lake Vostok geometry, J. Glaciol., 48 (160), 62-69.

(received March 12, 2006; accepted September 20, 2006) 